\section{(6) OPEN ACCESS}

Department of

Gastroenterological Surgery I, Hokkaido University Graduate School of Medicine, Sapporo, Japan

Correspondence to Dr Yuki Fujii, dr-big1023@hotmail.co.jp

Accepted 16 July 2016

\title{
Jejunal intussusception caused by metastasis of a giant cell carcinoma of the lung
}

\author{
Yuki Fujii, Shigenori Homma, Tadashi Yoshida, Akinobu Taketomi
}

\section{SUMMARY}

A 55-year-old woman was admitted to our hospital reporting of nausea, vomiting and anorexia. One month before admission, she had been diagnosed with lung cancer with intestinal metastasis. A CT scan confirmed intussusception due to intestinal metastasis and she underwent emergency laparoscopic surgery followed by resection of the primary lung cancer. Histopathological findings of the intestinal specimen suggested the metastasis was from a giant cell carcinoma of the lung, which had extensive necrosis. She was still alive without recurrence 11 months after the first surgery. Giant cell carcinoma of the lung is a rare type of non-small cell carcinoma and intestinal metastasis is one of the unique features. This type of tumour has such aggressive characteristics that oncological prognosis is reported to be extremely poor. In our case, however, complete surgical resection of both primary and metastatic tumours might result in a better outcome than has been reported.

\section{BACKGROUND}

Giant cell carcinoma of the lung is a rare form of poorly differentiated non-small cell lung carcinoma (NSCLC), which is classified as a sarcomatoid carcinoma according to the 2015 WHO classification. ${ }^{1}$ Giant cell carcinomas are composed entirely of giant cells and have specific patterns that do not resemble those of adenocarcinomas, squamous cell carcinomas or large cell carcinomas. ${ }^{1}$ These types are rare and account for $\sim 0.1-0.4 \%$ of all lung carcinomas. ${ }^{2-5}$ They are aggressive tumours and are prone to metastasize to other organs, including unusual locations such as the gastrointestinal tract and the retroperitoneal space. However, intussusception caused by the metastasis of a giant cell carcinoma of the lung is an extremely rare complication. Here, we present a rare case of a patient with jejunal intussusception caused by intestinal metastasis of a giant cell carcinoma of the lung.

\section{CASE PRESENTATION}

A 55-year-old woman who had monoclonal gammopathy of undetermined significance underwent screening using a whole-body CT scan and positron emission tomography (PET)-CT to rule out malignant myeloma. The whole-body CT scan showed a $36 \mathrm{~mm}$ sized mass on the left upper lung lobe and a mass forming wall thickness in the upper jejunum with an $8 \mathrm{~mm}$ lymph node swelling near the intestinal mass (figure 1A, B). A protruded tumour was detected in the upper jejunum using small bowel endoscopy (figure 2), and PET-CT revealed abnormal accumulation at the same lesion (figure 3). The fine-needle aspiration specimen showed that the tumour cells had large abundant cytoplasm that was densely eosinophilic, reminiscent of an epithelioid rhabdomyosarcoma, malignant melanoma or poorly differentiated carcinoma. The laboratory test revealed a highly elevated white cell count count $\left(38700 / \mathrm{mm}^{3}\right)$.
To cite: Fujii $Y$, Homma $S$, Yoshida T, et al. BMJ Case Rep Published online: [please include Day Month Year] doi:10.1136/bcr-2016216030
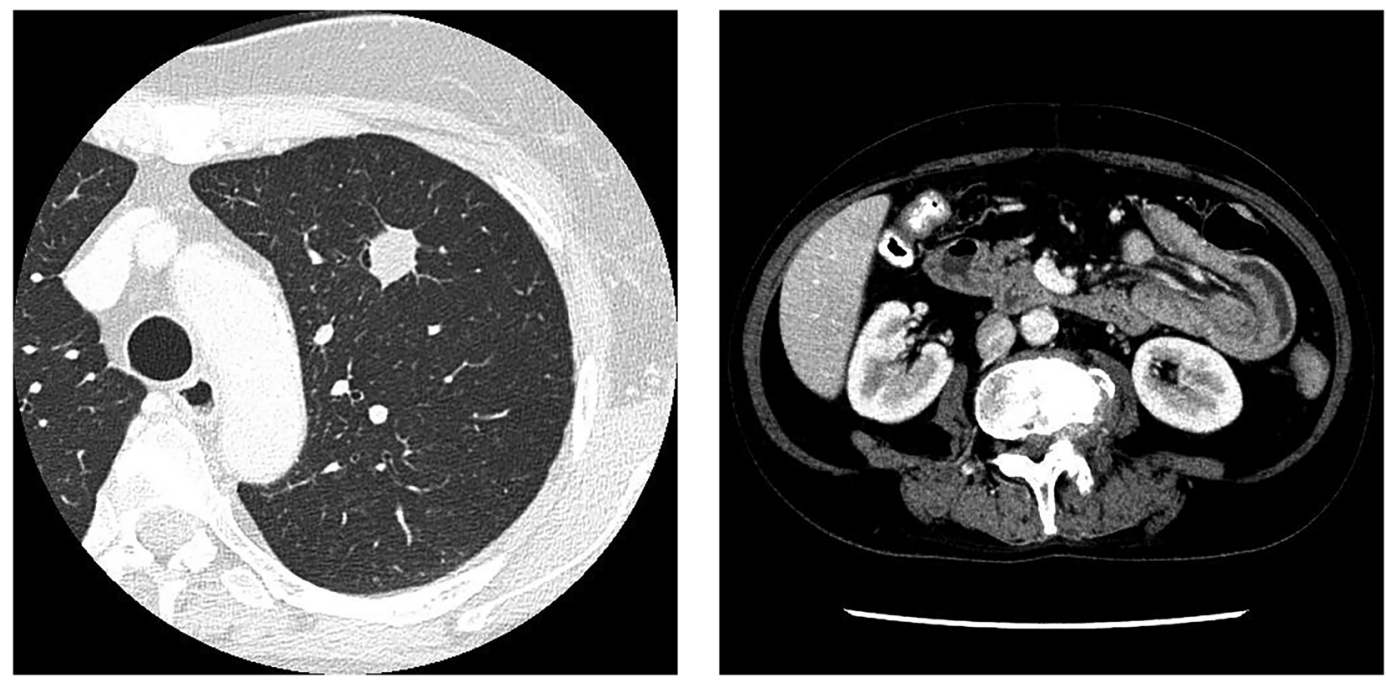

Figure 1 (A) Chest CT scan showed a $36 \mathrm{~mm}$ mass in the left upper lobe of the lung. (B) An abdominal CT scan showed a mass-forming wall thickness in the upper jejunum and a mesenteric lymph node swelling. 


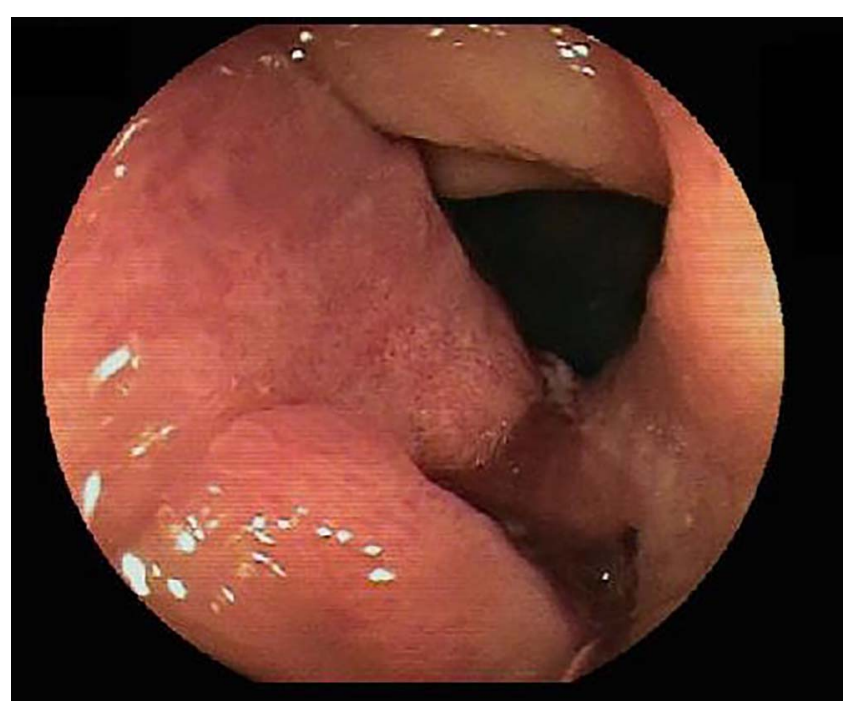

Figure 2 A small-bowel endoscopy revealed a protruded lesion in the upper jejunum.

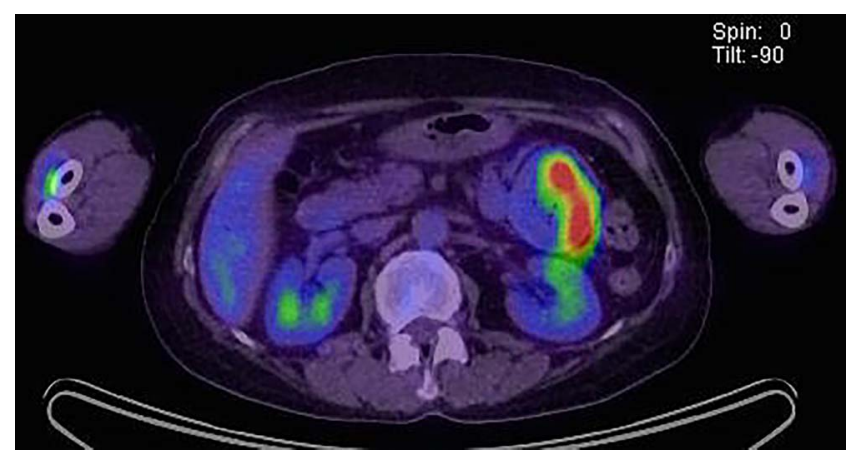

Figure $3{ }^{18} \mathrm{~F}$-fluorodeoxyglucose positron emission tomography revealed abnormal accumulation in the upper jejunum.

\section{DIFFERENTIAL DIAGNOSIS}

Considering the histological findings of the tumour and a lung lesion on CT scan, jejunal metastasis of the granulocyte-colony stimulating factor (G-CSF) secreting giant cell carcinoma of the lung was suspected. Other differential diagnoses were jejunal adenocarcinoma, malignant melanoma and anaplastic large cell lymphoma.

\section{TREATMENT}

One month later, she was admitted to our hospital reporting of nausea, vomiting and anorexia. We repeated the CT scan and diagnosed her with an intussusception of the jejunal tumour. We performed emergency laparoscopic surgery. The tumour with the intussusception was located in the upper jejunum $30 \mathrm{~cm}$ distal to the ligament of Treitz. After the intussusception was repositioned using the Hutchinson manoeuver, the jejunum was resected. The postoperative course was uneventful and the white cell count count at day 3 was decreased significantly to baseline after resection. Two months later, she underwent segmentectomy of the left upper lobe of the lung.

Histopathologically, the jejunal tumour was composed of a diffuse proliferation of tumour cells without a clear direction of differentiation, and relatively non-cohesive, pleomorphic mononucleated cells admixed with bizarre, frequently multinucleated giant cells that contained abundant eosinophilic cytoplasm. In addition, an increased number of tumour-infiltrating neutrophils and focal tumour cell emperipolesis were present (figure 4A, B). On immunohistochemical study, most tumour cells expressed cytokeratin (AE1/AE3 and CAM 5.2), vimentin and thyroid transcription factor-1 (TTF-1), while some expressed Napsin A and G-CSF. Although the immunopositivity of TTF-1 and Napsin A was supportive of metastasis from lung, the microscopic finding of the lung tumour was extensive necrosis with only scanty degenerated tumour cells remaining (figure 5). These histological findings corresponded with jejunal metastasis of a G-CSF-producing giant cell carcinoma of the lung.

\section{OUTCOME AND FOLLOW-UP}

The patient has been recurrence-free for 11 months since the first surgery. Although we planned to treat with adjuvant chemotherapy, which was the same as that used for treating NSCLC, she refused it and instead received only a follow-up examination.

\section{DISCUSSION}

Sarcomatoid carcinomas are a group of poorly differentiated NSCLCs that contain a component of sarcoma or sarcoma-like (spindle and/or giant cell) differentiation. Pleomorphic carcinomas, spindle cell carcinomas, giant cell carcinomas, carcinosarcomas and pulmonary blastomas are classified into this group according to the recent WHO classification. ${ }^{1}$ Sarcomatoid carcinomas are very rare diseases and have unique clinical features compared with other non-small cell carcinomas. As seen in our
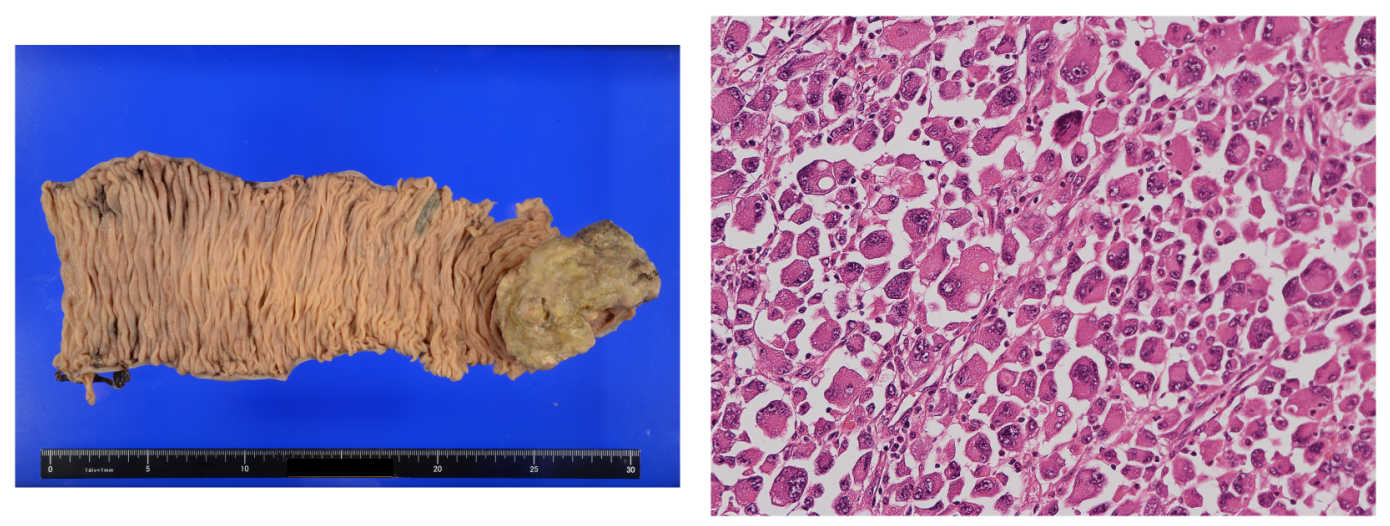

Figure 4 (A) The resected specimen of the jejunum. A protruded $89 \mathrm{~mm}$ mass can be seen to be invaginated into the distal jejunum. (B) The jejunal tumour was composed of a diffuse proliferation of tumour cells without a clear direction of differentiation, and relatively non-cohesive, pleomorphic mononucleated cells admixed with bizarre, frequently multinucleated giant cells that contained abundant eosinophilic cytoplasm. In addition, an increased number of tumour-infiltrating neutrophils and focal tumour cell emperipolesis were present. 


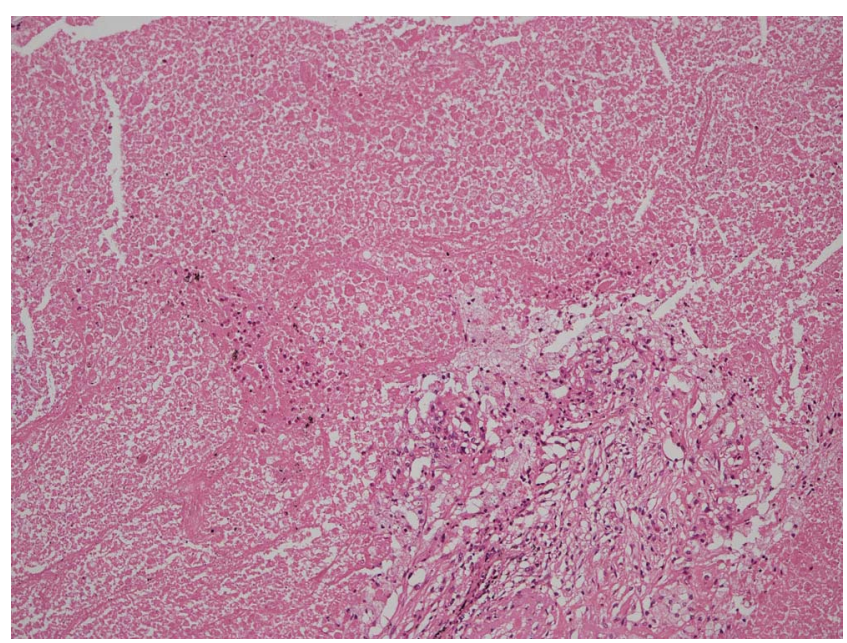

Figure 5 The microscopic findings of the lung tumour showing extensive necrosis with only scanty degenerated tumour cells remaining. case, sarcomatoid carcinomas sometimes cause an elevated inflammatory response due to the production of G-CSF and interleukin $6 .{ }^{6}$ Immunohistologically, TTF-1 and cytokeratin are detected in a significant percentage of sarcomatoid carcinomas. ${ }^{2}$ The outcome is significantly poorer than that of patients with other NSCLCs, and adjuvant chemotherapy and radiotherapy seem to be ineffective. Their aggressive characteristics such as large tumours, advanced-stage cancer and pleural invasions, result in higher rates of recurrence and lower survival rates. ${ }^{3} 5$ Some previous reports showed that the median survival time of patients with sarcomatoid carcinoma was 8-22.8 months and the 5 -year survival rate was $10-36.7 \% .^{2-5} 7$

Giant cell carcinomas of the lung sometimes metastasize to the gastrointestinal tract. Wellmann et $a l^{8}$ demonstrated that $17-25 \%$ of patients with pulmonary giant cell carcinomas had gastrointestinal metastases. However, intussusception caused by the intestinal metastasis of the primary lung carcinoma is rarely seen. Intussusception in adults accounts for $<5 \%$ of all intussusceptions and in $90 \%$ of adult cases is secondary to bowel

Table 125 reported cases of secondary intussusceptions caused by primary lung malignancies.

\begin{tabular}{|c|c|c|c|c|c|c|c|c|}
\hline Author & $\begin{array}{l}\text { Published } \\
\text { year }\end{array}$ & Age & Sex & Cancer cell type & $\begin{array}{l}\text { Tumour } \\
\text { stage } \\
\text { at initial } \\
\text { diagnosis }\end{array}$ & $\begin{array}{l}\text { Other metastasis } \\
\text { sites }\end{array}$ & $\begin{array}{l}\text { Time interval from } \\
\text { initial diagnosis to } \\
\text { intussusception }\end{array}$ & $\begin{array}{l}\text { Time interval from } \\
\text { intussusception to } \\
\text { death }\end{array}$ \\
\hline Katz et $a l^{16}$ & 1981 & 68 & M & Giant cell carcinoma & 4 & $\begin{array}{l}\text { Liver, } \\
\text { supraclavicular } \\
\text { lymph node }\end{array}$ & 1.6 months & NS \\
\hline Listrom et a $\left.\right|^{17}$ & 1988 & 63 & M & $\begin{array}{l}\text { Squamous cell carcinoma, } \\
\text { spindle cell type }\end{array}$ & 4 & Left adrenal gland & Simultaneously & NS \\
\hline $\begin{array}{l}\text { Eng and } \\
\text { Sabanathan }{ }^{18}\end{array}$ & 1992 & 60 & M & Carcinosarcoma & $2 B$ & Brain & 18 months & 6 months \\
\hline Issa and Mullen ${ }^{19}$ & 1992 & 61 & $\mathrm{M}$ & Adenocarcinoma, large cell type & 4 & Left 4th rib & 1 month & 1 month \\
\hline Testini et $a l^{20}$ & 2002 & 44 & M & Malignant melanoma & 4 & Brain & Simultaneously & 12 months (still alive) \\
\hline Yang et $a l^{21}$ & 2006 & 57 & M & Small cell carcinoma & 4 & Brain, ascite & 2 months & 3 months \\
\hline Alvarez et $a^{22}$ & 2006 & 50 & M & Big cell carcinoma & 4 & Vertebra & $\begin{array}{l}\text { NS (but } \\
\text { metachronous) }\end{array}$ & NS \\
\hline \multirow[t]{3}{*}{ Goh et $a^{23}$} & 2007 & 57 & M & $\begin{array}{l}\text { Pleomorphic associated } \\
\text { with adenocarcinoma }\end{array}$ & NS & $\begin{array}{l}\text { Para-aortic lymph } \\
\text { node, liver }\end{array}$ & 3 months & 7 months \\
\hline & & 40 & M & Large cell carcinoma & NS & Brain, bone & 4 months & 5 months \\
\hline & & 69 & M & Large cell carcinoma & NS & $\begin{array}{l}\text { Bone, liver, } \\
\text { cervical lymph node }\end{array}$ & 6 months & 9 months \\
\hline Kagohashi et al ${ }^{9}$ & 2007 & 59 & M & Large cell carcinoma & 4 & None & Simultaneously & 6 months \\
\hline Pollheimer et $a l^{13}$ & 2009 & 65 & $\mathrm{~F}$ & Pleomorphic carcinoma & 4 & NS & Simultaneously & NS \\
\hline Chiu et $a l^{24}$ & 2009 & 87 & M & $\begin{array}{l}\text { Poorly differentiated } \\
\text { adenocarcinoma }\end{array}$ & NS & Gingiva & Simultaneously & 2.7 months \\
\hline Shi et al ${ }^{14}$ & 2009 & 61 & M & $\begin{array}{l}\text { Pleomorphic sarcomatoid } \\
\text { carcinoma }\end{array}$ & 4 & $\begin{array}{l}\text { Right adrenal gland, } \\
\text { liver, brain }\end{array}$ & 17 months & 4 months \\
\hline Kini et $a l^{25}$ & 2010 & 78 & M & Adenocarcinoma & NS & None & 7 months & 5 months (still alive) \\
\hline Otera et $a l^{10}$ & 2010 & 63 & $M$ & Large cell carcinoma & 4 & None & Simultaneously & 0.9 months \\
\hline Lee $e t a l^{26}$ & 2010 & 74 & M & $\begin{array}{l}\text { Poorly differentiated } \\
\text { adenocarcinoma }\end{array}$ & 4 & None & Simultaneously & NS \\
\hline Rashid et a $\left.\right|^{27}$ & 2011 & 57 & M & Pleomorphic carcinoma & 4 & None & Simultaneously & 3 months \\
\hline Jarmin et $a l^{11}$ & 2012 & 75 & M & Small cell carcinoma & 4 & None & Simultaneously & NS \\
\hline Guner et $a l^{28}$ & 2012 & 71 & M & Sarcomatoid carcinoma & $3 \mathrm{~A}$ & None & 12 months & 9 months \\
\hline Wou et $a l^{15}$ & 2013 & 77 & $\mathrm{~F}$ & Non-small cell carcinoma & 4 & NS & Almost simultaneously & 2 months \\
\hline Lin et $a l^{29}$ & 2014 & 78 & M & Pleomorphic carcinoma & 4 & None & Simultaneously & 3 months \\
\hline Jung et $a l^{30}$ & 2014 & 63 & M & Pleomorphic carcinoma & $3 \mathrm{~A}$ & $\begin{array}{l}\text { Bone, mediastinal } \\
\text { lymph node }\end{array}$ & 5 months & NS \\
\hline Mandeville et al ${ }^{12}$ & 2015 & 49 & $\mathrm{~F}$ & Giant cell carcinoma & 4 & $\begin{array}{l}\text { Vertebra, cervical } \\
\text { lymph node, brain }\end{array}$ & Simultaneously & 6 months \\
\hline Present case & 2015 & 55 & $\mathrm{~F}$ & Giant cell carcinoma & 4 & None & 1 month & $\begin{array}{l}11 \text { months (still alive) } \\
\text { NS }\end{array}$ \\
\hline
\end{tabular}

NS, not stated. 
diseases. $^{9-12}$ Malignancy is found in $6-30 \%$ of small bowel intussusceptions following surgical resection, and lung cancers account for $21.6 \%$ of these cases. ${ }^{13-15}$

We examined the prevalence of secondary intussusceptions caused by primary lung malignancies by performing a PubMed search up until November 2015 using the key words 'intussusception' and 'lung cancer/carcinoma'. Inclusion criteria were case reports, case series and cohort studies that investigated patients with intussusception caused by primary lung malignancies. Exclusion criteria included studies in languages other than English. We found 25 cases, including our case, which corresponded to the criteria presented in 22 publications. $^{9-30}$ The data are shown in table 1 . The male to female ratio was $21: 4$ and the average age was 63.2 years old ( $40-87$ years old). The most common tumour types of the primary lung lesion were sarcomatoid carcinomas (44\%), including giant cell carcinomas (12\%), followed by large cell carcinomas (20\%), adenocarcinomas (16\%), small cell carcinomas (8\%), squamous cell carcinomas (4\%), non-small cell carcinomas (4\%) and malignant melanomas (4\%). This result supports the fact that sarcomatoid carcinomas are more likely to develop intestinal metastases. Almost all cases were diagnosed in advanced stages and intussusception was the first symptom in 44\% (11/25) of all cases. The prognosis of patients with intussusception was particularly poor because of metastatic lung cancer. The median survival time after diagnosis of intussusception was 5 months (range, 0.9-12 months).

Accordingly, we considered that the intussusception because of lung cancer metastases was particularly rare, and prognoses of such cases were extremely poor. In contrast, our patient was still alive without recurrence for 11 months after the first surgery. Although the exact reason remains unclear, it seems possible that the better prognosis of this patient was due to complete resection of both primary lung lesion and intestinal metastasis. Shoji et $a l^{31}$ reported a case of a pulmonary giant cell carcinoma with metastases to the small intestine, which resulted in more than 3-year disease-free survival after aggressive surgical resection and chemotherapy. Although the standard therapy for giant cell carcinomas of the lung with intestinal metastasis has not been established, we believe that aggressive surgical resection is an effective strategy and plays an important role in the management of such cases.

\section{Learning points}

- Giant cell carcinomas of the lung are rare tumours whose oncological prognoses are extremely poor and intestinal metastasis is one of the unique features of them.

- Intussusception because of intestinal metastasis of lung cancer is a rare complication.

- Although pulmonary giant cell carcinomas with intestinal metastases have a poor prognosis, complete surgical resection of tumours might result in a better outcome.

Acknowledgements The authors would like to thank Dr Takashi Fujisawa for his help in preparing this report.

Contributors $\mathrm{YF}$ is a main author and writes fundamentals of this article. $\mathrm{SH}$ is the chief doctor of this patient and got informed consent from her. He also plays a role of reviewer for this article. TY provides scientific and grammatical advice to this article. AT critically reviews and revises this article.

Competing interests None declared.

\section{Patient consent Obtained.}

Provenance and peer review Not commissioned; externally peer reviewed.

Open Access This is an Open Access article distributed in accordance with the Creative Commons Attribution Non Commercial (CC BY-NC 4.0) license, which permits others to distribute, remix, adapt, build upon this work non-commercially, and license their derivative works on different terms, provided the original work is properly cited and the use is non-commercial. See: http://creativecommons.org/ licenses/by-nc/4.0/

\section{REFERENCES}

1 Travis WD, Brambilla E, Burke AP, et al. World health organization classification of tumours of the lung, pleura, thymus and heart. 4th edn. Lyon, France: IARC Press, 2015.

2 Rossi G, Cavazza A, Sturm N, et al. Pulmonary carcinomas with pleomorphic, sarcomatoid, or sarcomatous elements: a clinicopathologic and immunohistochemical study of 75 cases. Am J Surg Pathol 2003;27:311-24.

3 Mochizuki T, Ishii G, Nagai K, et al. Pleomorphic carcinoma of the lung. Clinicopathologic characteristics of 70 cases. Am J Surg Pathol 2008;32:1727-35.

4 Huang SY, Shen SJ, Li XY. Pulmonary sarcomatoid carcinoma: a clinicopathologic study and prognostic analysis of 51 cases. World J Surg Oncol 2013;11:252.

5 Martin LW, Correa AM, Ordonez NG, et al. Sarcomatoid carcinoma of the lung: a predictor of poor prognosis. Ann Thorac Surg 2007;84:973-81.

6 Sakata S, Sasaki J, Tanaka R, et al. [A case of stage IIIB pulmonary pleomorphic carcinoma that responded well to chemoradiotherapy and surgery]. Nihon Kokyuki Gakkai Zasshi 2011;49:131-4.

7 Fishback NF, Travis WD, Moran CA, et al. Pleomorphic (spindle/giant cell) carcinoma of the lung. A clinicopathologic correlation of 78 cases. Cancer 1994;73:2936-45.

8 Wellmann KF, Chafiian Y, Edelman E. Small bowel perforation from solitary metastasis of clinically undetected pulmonary giant cell carcinoma. Am J Gastroenterol 1969;51:145-50.

9 Kagohashi K, Kadono K, Satoh $H$, et al. Intussusception due to intestinal metastasis from lung cancer. Lung Cancer 2007;57:247-8.

10 Otera H, Ikeda F, Nakagawa S, et al. Intussusception of small intestine due to metastasis of large cell carcinoma of the lung with a rhabdoid phenotype. Eur Respir Rev 2010;19:248-52.

11 Jarmin R, Azman A, Rahim R, et al. A rare case of intussusception associated with metastasized small cell carcinoma of lung. Acta Med Iran 2012;50:782-4.

12 Mandeville $Y$, de Gheldere C, Vanclooster P. Small bowel intussusception caused by multiple intestinal metastases from a giant cell carcinoma of the lung: a case report. Acta Chir Belg 2015;115:49-51.

13 Pollheimer MJ, Eberl T, Baumgartner K, et al. Ileocecal intussusception caused by lung cancer metastasis. Wien Klin Wochenschr 2009;121:413-16.

14 Shi B, Gaebelein G, Hildebrandt B, et al. Adult jejunojejunal intussusception caused by metastasized pleomorphic carcinoma of the lung: report of a case. Surg Today 2009;39:984-9.

15 Wou C, Sharp E, Johnson L. Intussusception secondary to a solitary peritoneal lung metastasis. BMJ Case Rep 2013. doi:10.1136/bcr-2012-008370

16 Katz ME, Hahn IS, Job GG, et al. Intussusception as an unusual complication of metastatic lung cancer. Conn Med 1981;45:220-2.

17 Listrom MB, Davis M, Lowry $\mathrm{S}$, et al. Intussusception secondary to squamous carcinoma of the lung. Gastrointest Radiol 1988;13:224-6.

18 Eng J, Sabanathan S. Carcinosarcoma of the lung with gastrointestinal metastasis. Case report. Scand J Thorac Cardiovasc Surg 1992;26:161-2.

19 Issa K, Mullen KD. Large-cell carcinoma of the lung. With major bleeding and intussusception. J Clin Gastroenterol 1992;15:142-5.

20 Testini M, Trabucco S, Di Venere B, et al. Ileal intussusception due to intestinal metastases from primary malignant melanoma of the lung. Am Surg 2002;68:377-9.

21 Yang CJ, Hwang JJ, Kang WY, et al. Gastro-intestinal metastasis of primary lung carcinoma: clinical presentations and outcome. Lung Cancer 2006;54:319-23.

22 Alvarez Laso C, Paredes Aracil E, Azcano González E, et al. Small bowel occlusion due to intussusception of a single metastasis of lung cancer. Clin Trans/ Oncol 2006;8:833-4.

23 Goh BK, Yeo AW, Koong HN, et al. Laparotomy for acute complications of gastrointestinal metastases from lung cancer: is it a worthwhile or futile effort? Surg Today 2007;37:370-4.

24 Chiu WK, Lin YC, Wang LT, et al. Jejunojejunal intussusception secondary to metastasis from adenocarcinoma of the lung-a case report. Acta Chir Belg 2009;109:519-22.

25 Kini S, Kapadia RM, Amarapurkar A. Intussusception due to intestinal metastasis from lung cancer. Indian J Pathol Microbiol 2010;53:141-3. 
26 Lee JW, Kim SK, Park JW, et al. Unexpected small bowel intussusception caused by lung cancer metastasis on 18F-fluorodeoxyglucose PET-CT. Ann Thorac Surg 2010;90:2037-9.

27 Rashid S, Rajan D, Jacob R, et al. Colonic metastases from pleomorphic carcinoma of the lung presenting as an ileocecal intussusception. ISRN Gastroenterol 2011;2011:137139.

28 Guner A, Karyagar S, Livaoglu A, et al. Small bowel intussusception due to metastasized sarcomatoid carcinoma of the lung: a rare cause of intestinal obstruction in adults. Case Rep Surg 2012;2012:962683.
29 Lin MW, Wu CT, Chang YL. Intussusception caused by intestinal metastasis from lung pleomorphic carcinoma. Ann Thorac Cardiovasc Surg 2014; $20: 635-8$.

30 Jung SP, Han KM, Bae JW, et al. Recurrent intussusception caused by intestinal metastasis of pulmonary pleomorphic carcinoma. Kaohsiung J Med Sci 2014;30:378-9.

31 Shoji F, Maruyama R, Okamoto T, et al. Long-term survival after an aggressive surgical resection and chemotherapy for stage IV pulmonary giant cell carcinoma. World J Surg Oncol 2005;3:32.

Copyright 2016 BMJ Publishing Group. All rights reserved. For permission to reuse any of this content visit http://group.bmj.com/group/rights-licensing/permissions.

BMJ Case Report Fellows may re-use this article for personal use and teaching without any further permission.

Become a Fellow of BMJ Case Reports today and you can:

- Submit as many cases as you like

- Enjoy fast sympathetic peer review and rapid publication of accepted articles

- Access all the published articles

- Re-use any of the published material for personal use and teaching without further permission

For information on Institutional Fellowships contact consortiasales@bmjgroup.com

Visit casereports.bmj.com for more articles like this and to become a Fellow 